Kristjan Mavri

\title{
Cormac McCarthy and Popular Culture A New Old West
}

In a rare interview, Cormac McCarthy revealed his penchant for the legendry of the American West: „I've always been interested in the Southwest $[. .$.$] There isn't a place in the world you can go where they$ don't know about cowboys and Indians and the myth of the West" [Woodward 1992: 9]. Indeed, the myth of the „Old West” or „Wild West” shimmers with such ideas as the frontier, endless opportunity, rugged individualism, self-transformation, the democratic impulse, justice and honor, and it is often evoked by images of the cowboy hat, the horse, the six-gun, and vast stretches of open land populated with mesas, buttes, and snow-rimmed peaks. The universal and overpowering appeal of the countless incarnations of the western imaginary in literature, cinema, television, radio, and painting is self-evident. And while the western's ability to maintain its hold as the most popular of American genres may have been partly due to the exhilarating and romantic plots, as suggested by Henry Nash Smith, the significance of the West lay in the utopian vision it voices, matching Americans' aspirations-economic, social, political, and personal.

Westerns fall short of explaining American history, though. They are no longer bound up with historical possibilities as they seemed to be in the days of Frederick Jackson Turner. ${ }^{1}$ „Western plots”, Lee Clark

${ }^{1}$ Frederick Jackson Turner (1861-1932) was the author of „The Significance of the Frontier in American History", a paper he delivered at the meeting of the American Historical Association during the Chicago World's Fair in 1893. The Turner thesis characterized the spirit and the success of the United 
Mitchell points out, „have had only the vaguest basis in actual conditions - conditions that in any event were marginal to the consciousness of most Americans" [1998: 5]. In a similar vein, Patricia Nelson Limerick writes, „In the popular imagination, the reality of conquest dissolved into stereotypes of noble savages and noble pioneers struggling quaintly in the wilderness [...]; the subject of conquest was the domain of mass entertainment and the occasion for lighthearted national escapism" [1987: 19]. New western revisionism began before Limerick's highly influential study The Legacy of Conquest; in the 1960s in the United States, the preponderance of ethnic, antiracist, feminist, and environmental movements precipitated a critical shift in how we read the dominant texts (stories, myths, histories, political documents) of the American West.

This revisionist impetus has also infused western literature. „[L]ong the unchallenged territory of the pulp specialist”, as David H. Evans puts it [qtd. in Hage 2010: 167], the western was taken up by more literary authors and historiographers in an effort to rewrite the traditional monochromatic narrative of western expansionism. „The reinterpretation sought to reveal [the western] as carefully contrived propaganda on behalf of an aggressive, imperialistic and racist white society", writes David H. Murdoch [2001: x]. Authors such as Thomas Berger, Annie Proulx, Larry McMurtry, Leslie Marmon Silko, and Ana Castillo have undertaken to replace, upset, and dismantle narratives that perpetuate the sort of colonial relations which continue to shape the American West-eschewing the heroic optimism and stepping

States as directly tied to the country's westward expansion: „The existence of an area of free land, its continuous recession, and the advance of American settlement westward, explain American development" [Turner 1921: 7]. It was in this empty western landscape - the meeting ground of civilization and savagery-that the rugged and independent American character was continually being forged. „The frontier individualism has from the beginning promoted democracy" [1921: 23], Turner asserted. His stylized history silences the voices of Native American peoples and women, and naturalizes the process whereby „primitive Indian life had passed away” [1921: 14]. 
forth into new and troubled territories of race, ethnicity, gender, and environmental behavior.

Cormac McCarthy's place among western revisionists is, at best, a problematic and tenuous one, Sara L. Spurgeon reports, recalling that he „has been accused of sexism for not creating more female characters, of racism for writing mainly about Anglos, and of romanticizing violent, politically incorrect cowboys. He has been seen by many as the prototypical white male Western writer" [2005: 17]. And yet, his 1985 Blood Meridian, Or the Evening Redness in the West in particular has been read as both a continuation and rejection of the traditional generic archetypes. The novel reproduces the very histories, stories, and myths about the American West that have for so long engaged the popular imagination. In doing so, however, McCarthy recasts the lens through which we view them, in effect deconstructing simplistic antinomies and the civilization-versus-savagery paradigm the western was to uphold.

This article, then, delineates some of the properties of the popular western in its myriad incarnations and traces how McCarthy reconfigures them to present his metaphysical vision of the empty landscape into which violence intrudes. In other words, it sets Blood Meridian against a backdrop of constitutive features of the popular western to show how McCarthy problematizes generic tropes. Boiling down any genre to a selection of recurring themes and images inevitably runs the risk of reductionism. „In fact”, Murdoch contends, „plot variation has been enormous over the last ninety years; but it is also true that, more than any genre, the Western operates within conventions and these conventions are not the framework but the genre's essence" [2001: ix]. On the constancy and change of the genre of the western, Lee Clark Mitchell writes the following:

While no formula binds such varied texts together, the Western has nonetheless persisted as what might be called a mode through a long history of changing formats: from „penny dreadfuls” and dime novels through „pulp” and "slick" magazines; from silent, black-and-white one-reelers through the sound era of Technicolor film; from half-hour weekly television programs through blockbuster miniseries. Despite advances in production technique and evolutions in aesthetic form, despite flagrant accommodations to less 
local concerns (in anti-Nazi and anti-Communist Westerns, in singing cowboy and film noir Westerns), the mode never seems to lose what Wittgenstein referred to as a „family resemblance” [...]. [Mitchell 1998: 7]

His categorization of the western as a literary mode notwithstanding, what Mitchell claims rings true: despite the changes to its generic form and its flexibility to address an array of cultural anxieties and ideological issues - this is in part also the reason for its enduring appealthe "hard core” of the genre has remained relatively unchanged since its advent, that is, the persistence of the utopian view of the West and the individualism, justice, and democratic values it exemplified. The attributes championed by the genre have fed the American social and political sensibility - the notion that Americans share a unique destiny and role in the world. This creed (given considerable credence by the Turner thesis) can be expressed as follows: The empty land that lay to the West held endless opportunity and hope, but it was untamed and savage, like the tribes that peopled it. Frontiersmen first had to blaze a trail and deal with the Indian menace before pioneers could come to seize the free land and bring civilization with resolute inevitability. It was through the conviction, action, and self-reliance of individuals that the West was won, and though the rugged individualism of frontier life stood in stark opposition to communal spirit, the egalitarianism and equality that pioneers pursued soon birthed basic democratic government. This was a time of black and white morality, but it was also a time of ethnic violence done in the name of advancing civilization. Frontiersmen hence had to possess uncanny courage and skill to brave the perils of the West. Even those who thought themselves above the law might be seen as heroes if law served only the personal interest of arbitrary authority. The closing of the frontier at the end of the nineteenth century saw also the closing of a crucial chapter in American history. The frontier experience inscribed on the collective American subconscious the core values of optimism, individualism, self-reliance, egalitarianism, and democratic integrity. ${ }^{2}$

2 The interpretation of America's past advanced in this paragraph is indebted to Murdoch [2001:2-3]. 
What is described above is not history, nor is it romanticized history - it is myth. It is a vision that Jordana Finnegan, using Daniel Cooper Alarcón's notion of the palimpsest, figures as „a site where texts have been superimposed onto others in an attempt to displace earlier or competing histories" [2008: 5]. The saga of the conquest of the West, historiographers now agree, is in essence white and Anglocentric, and renders invisible the Spanish-American contribution in the conquest of the West, the black cowboy, and the role of women. Indians vacillated between the roles of savages and noble savages, depending on the public opinion [Murdoch 2001: 9]. This myth has functioned to legitimize and solve the "fundamental conflict between tenaciously held ideals and a reality which defied them" [2001: 17]. Bits of history and pure fiction were conflated by writers that wanted to establish a new literary tradition and was seized upon by a public drawn to escapism. Over time and through countless retellings, stories illustrating frontier experiences grew into legends-legends that were endorsed by historians and politicians.

McCarthy's most historically fraught novel and the first to be set in the Southwestern borderlands, Blood Meridian chronicles the grim exploits of the Glanton Gang, who worked as scalphunters in the period following the Mexican-American War (1846-1848), before devolving into pillagers and murderers, and the bloody swath they cut across the Sonora desert between Texas and Mexico. Blood Meridian has done much to reveal a West that is very different from that of myth. It moves against what Limerick has called an American refusal to face „up to the bitter reality of violence embedded in landscapes that Americans would later come to see as places of natural innocence, separated from the tragedy of history" [2008: xix] and confronts the complexities that arise in the history of the encounter between Indians and Euro-Americans.

Blood Meridian depicts violence that Vince Brewton has deemed „informal violence [...] violence that is fragmentary, unconsidered, "random,” or „senseless”” as opposed to „violence formalized by history, justice, or any moral codes" [qtd. in Hage 2000: 165]. Indeed, if traditional historical and fictional accounts served to rationalize, legitimize, and make order out of the mindless violence and chaos, 
Blood Meridian reveals that chaos and violence as the heart and core of western civilization. The desert deathscape of the novel is a site where moral law is not to be found and where such words as justice, honor, and cowboy code echo empty. McCarthy dispenses altogether with the binary notions of right and wrong, good and evil, victim and villain, and implicates everyone, regardless of their race, color, creed, or class, in the perpetuation of violence. Consider this early description of a large band of Comanche, ,a legion of horribles, hundreds in number, half naked or clad in costumes attic or biblical or wardrobed out of a fevered dream with the skins of animals and silk finery and pieces of uniform still tracked with the blood of prior owners" [McCarthy 1985: 52], as they descend upon Captain White's troop of filibusters, „seizing them up by their hair and passing their blades about the skulls of the living and the dead alike and snatching aloft the bloody wigs and hacking and chopping at the naked bodies, ripping off limbs, heads, gutting the strange white torsos and holding up great handfuls of viscera, genitals, some of the savages so slathered up with gore they might have rolled in it like dogs and some who fell upon the dying and sodomized them with loud cries to their fellow" [1985: 54].

Such episodes distance the novel from postcolonial activism or revisionist works that seek to invert the victim/aggressor dynamic. It is not only the Comanche who have a taste for mindless violence; the barbarism of the Glanton Gang, contracted by Angel Trias, the Mexican governor of Chihuahua, to protect his community from the Comanche, may well surpass that of the Indians. Their appearance parallels to the Indians:

[...] a pack of viciouslooking humans mounted on unshod indian ponies riding half drunk through the streets, bearded, barbarous, clad in skins of animals stitched up with thews and armed with weapons of every description [...] and the trappings of their horses fashioned out of human skin and their bridles woven up from human hair and decorated with human teeth and the riders wearing scapulars or necklaces of dried and blackened human ears [...] dangerous, filthy, brutal, the whole like a visitation from some heathen land where they and others like them fed on human flesh [McCarthy 1985: 78]. 
The atrocities the scalphunters commit are also on a par with the Comanche. As they fall upon a camp of Gilenos ${ }^{3}$,

[...] some of the men were moving on foot among the huts with torches and dragging the victims out, slathered and dripping with blood, hacking at the dying and decapitating those who knelt for mercy. There were in the camp a number of Mexican slaves and these ran forth calling out in spanish and were brained or shot and one of the Delawares emerged from the smoke with a naked infant dangling in each hand and squatted at a ring of midden stones and swung them by the heels each in turn and bashed their heads against the stones so that the brains burst forth through the fontanel in a bloody spew [...] [1985: 156].

The absence of order, control, or social sanctions sees people reduced to commodities, as the scalphunters ultimately turn on the very community they are bound to protect in their fervor to collect bounties. ${ }^{4}$ They indiscriminately kill any and all with black hair: peaceful Indians, women, children, Mexican soldiers and citizens [Hage 2010: 32]. Murdoch writes that westerns „consistently pit the lone hero, often as not on behalf of the community, against enemies who impede "progress" - the lands itself, Indians, criminals and those who would abuse power" [2001: ix]. McCarthy reveals a darker reality that lurks beneath the clichéd and romanticized stories of the West; here, it is Glanton's band of marauders - a multicultural microcosm of criminals and degenerates, Anglo, Indian, Mexican, black and white alike - that abuse power in their perverted „civilizing through savagery”.

McCarthy is uncompromising and indiscriminate in how he portrays „a world in which savagery cuts across cultures” [Hage 2010: 32]. Violence is a universal human trait, and the events that

3 A tribe of Apache Indians.

${ }^{4}$ During the 1840 s and 1850 s northern Mexican regions were frequently besieged by the Apache and Comanche, and often employed mercenaries to fight back the native threat. Mercenaries used scalps as receipts for what was at the time a significant payment [Hage 2010: 30-31]. 
are the foundation of much American culture are just the latest in the ebb and flow of civilizations, empires, and societies. McCarthy makes Judge Holden, the novel's monstrous and omnipresent antagonist, his mouthpiece, when he comments on some ruins left by the Anasazi: ${ }^{5}$ „What is true of one man, said the judge, is true of many. [...] They quit these parts, routed by drought or disease or wandering bands of marauders, quit these parts ages since and of them there is no memory” [McCarthy1985: 146]. And he continues: „This you see here, these ruins wondered at by tribes of savages, do you not think that this will be again? Aye. And again" [1985: 147]. In a similar vein, one of the three epigraphs that open the novel describes a 300,000-year-old fossil skull uncovered in Ethiopia that „shows evidence of having been scalped" [1985: preface page].

And what of the natural landscape, the aesthetic and psycho-cultural foundation for what Nash Smith called an „objectified mass dream" [1950: 91], that overarching presence in western fiction that gives meaning and substance to the dogma of manifest destiny? Jane Tompkins notes that „[t]he interaction between hero and landscape lies at the genre's center, overshadowed in the popular image of the Western by gunfights and chases, but no less essential to the experience Westerns provide. In the end, the land is everything to the hero; it is both the destination and the way. He courts it, struggles with it, defies it, conquers it, and lies down with it at night" [1992: 81]. The terrain of the popular western holds promise and possibility, terror and pain, but ultimately restores the hero: „A welcoming grove of aspens, a spring, and a patch of grass provide shelter and sustenance. A campfire and the setting sun give visual pleasure and comfort, while trickling water and a horse cropping grass make soothing noises. If

5 The Anasazi were an ancient American Indian culture in what is now the Southwestern United States.

${ }^{6}$ For an intriguing Freudian psycho-history of the metaphorical appearance of "land-as-woman” in male American literature, see Kolodny A. [1975], The Lay of the Land: Metaphor as Experience and History in American Life and Letters, University of North Carolina Press, Chapel Hill. 
nature's wilderness and hardness test his strength and will and intelligence, they also give him solace and refreshment" [1992: 81]. The landscape exists to further the hero on his adventure, testing his resolve and providing respite.

A fundamental question raised by Blood Meridian is whether humans occupy a privileged position in relation to other animate and inanimate objects, „whether the stuff of creation may be shaped to man's will or whether his own will is just another kind of clay" [McCarthy 1985: 5]. The following often quoted passage suggests that they in fact do not:

In the neuter austerity of that terrain all phenomena were bequeathed a strange equality and no one thing nor spider nor stone nor blade of grass could put forth claim to precedence. The very clarity of these articles belied their familiarity, for the eye predicates the whole on some features or part and here was nothing more luminous than another and nothing more enshadowed and in the optical democracy of such landscapes all preference is made whimsical and a man and a rock become endowed with unguessed kinships [1985: 247].

The relationship between human beings and nature, Dana Phillips maintains, is not antagonistic, that is, the two do not contend for supremacy [1996: 446]. Nor does the natural world of Blood Meridian sustain any kind of moral structure that would bring out the best in the hero and wage conflict against the villain. The natural world is just that; it does not act on behalf of some higher principle, some higher will that shapes the fate of men:

Far out on the desert to the north dustspouts rose wobbling and augered the earth and some said they'd heard of pilgrims borne aloft like dervishes in those mindless coils to be dropped broken and bleeding upon the desert again and there perhaps to watch the thing that had destroyed them lurch onward like some drunken djinn and resolve itself once more into the element from which it sprang. Out of that whirlwind no voice spoke and the pilgrim lying in his broken bones may cry out and in his anguish he may rage, but rage at what? [1985: 111] 
This „terra damnata" [1985: 61] acts just as violently, randomly, and profanely as the scalphunters; „In the raw orchestration of the book's events, the world of nature and the world of men are parts of the same world, and are equally violent and indifferent to each other" [Phillips 1996: 447]. Consider another description of nature, in which the horsemen navigate inhospitable volcanic badlands: „they crossed the malpais afoot, leading the horses upon a lakebed of lava all cracked and reddish black like a pan of dried blood, threading those badlands of dark amber glass like the remnants of some dim legion scrabbling up out of a land accursed [...]. They crossed a cinderland of caked slurry and volcanic ash imponderable as the burnedout floor of hell [McCarthy 1985: 251]. Such passages reiterate the „unguessed kinships” between objects and men, both of whom are malevolent and emptied of any moral resonance.

Blood Meridian engages in a critical dialogue with the genre but it is also shaped by attraction to the traditional code of the western. It shows that the western is a shifting form able to address and stir binary articulations of cultural identity. McCarthy revisits the history of the American West and engenders a necessity of confronting the world as it is, which is to say a world governed not by logic or moral law but by mindless violence, ethnic, cultural, and environmental. Humans devise stylized narratives that mediate the raw experience of the world, but history cannot be reversed. The zenith of their progress is simultaneously a bloody nadir — or, as the judge would have it, „The way of the world is to bloom and to flower and die but in the affairs of men there is no waning and the noon of his expression signals the onset of night. His spirit is exhausted at the peak of its achievement. His meridian is at once his darkening and the evening of his day" [1985: 146-147].

\section{Literature}

Finnegan J. [2008], Narrating the American West: New Forms of Historical Memory, Amherst, Cambria Press, New York.

Hage E. [2010], Cormac McCarthy: A Literary Companion, McFarland \& Company, Jefferson, NC. 
Limerick P. N. [1987], The Legacy of Conquest: The Unbroken Past of the American West, W. W. Norton \& Company, New York.

Limerick P. N. [2008], „Foreword”, [in:] K. Jacoby, Shadows at Dawn: a Borderlands Massacre and the Violence of History, Penguin Press, New York.

McCarthy C. [1985], Blood Meridian, Or the Evening Redness in the West, Random House, New York.

Mitchell L.C. [1998], Westerns: Making the Man in Fiction and Film, University of Chicago Press, Chicago.

Murdoch D.H. [2001], The American West: The Invention of Myth, University of Nevada Press, Reno.

Nash Smith H. [1950], Virgin Land: The American West as Symbol and Myth, Harvard University Press, Cambridge, MA.

Phillips D. [1996], „History and the Ugly Facts of McCarthy's Blood Meridian", American Literature 68.2, 433-460, JSTOR, Web. [access 17.10. 2012].

Spurgeon S.L. [2005], „Introduction”, [in:] Exploding the Western: Myths of Empire on the Postmodern Frontier, Texas A\&M University Press, College Station.

Spurgeon S.L. [2005], Exploding the Western: Myths of Empire on the Postmodern Frontier, Texas A\&M University Press, College Station.

Tompkins J.H. [1992], West of Everything: The Inner Life of Westerns, Oxford University Press, New York.

Turner F.J. [1921], „The Significance of the Frontier in American History”, [in:] The Frontier in American History, New York, Henry Holt and Company, Project Gutenberg, Web. [access 12.10.2012].

Woodward R.B. [1992], „McCarthy's Venomous Fiction”, The New York Times Magazine, April 19, http://www.nytimes.com/1992/04/19/magazine/ cormac-mccarthy-s-venomous-fiction.html?pagewanted=1 ?pagewanted $=1$. Web. [access 10 Oct. 2012]. 